\title{
SECTARIAN WAR IN THE MIDDLE EAST: IRAN, SAUDI ARABIA, PAKISTAN AND AN UNENDING WAR FOR REGIONAL HEGEMONY
} Farrukh Faheem $^{1}$, Sajjad Hussain ${ }^{2}$, Wang Xingang ${ }^{3 *}$

${ }^{1}$ Ph.D. in World History, Northwest University Xian, China, and Assistant Professor of History, and Teaches, GPC Rajanpur, Punjab, Pakistan; ${ }^{2}$ Ph.D., Scholar, Department of Political Science, Islamia University Bahawalpur, Pakistan; ${ }^{3 *}$ Professor of World History, and Director of China's Pioneer Syrian Research Centre at Northwest University of Xian, China.

Email: ${ }^{1}$ farrukhfaheem5050@gmail.com, ${ }^{2}$ sajjadjoinme@yahoo.com, ${ }^{3 *}$ wangxingang@snu.edu.cn Article History: Received on $21^{\text {st }}$ May 2021, Revised on $16^{\text {th }}$ June 2021, Published on $25^{\text {th }}$ June 2021

\section{Abstract}

Purpose: This paper aims to explore the current chaotic condition of the Middle East that was fueled by the traditional competition between Saudi Arabia and Iran. s state and society in every field of life.

Principal Findings: The paper argues that the Saudi-Iran's sectarian proxy warfare in the Middle East is a means to counter each other's regional influence that has adverse implications for the internal security of Pakistan that can destroy its economy as well.

Methodology: This research is based on a qualitative approach and deductive method. The paper answers four main queries: To what extent the Iran-Saudi Rivalry a result of sectarian aspirations? How are both countries using proxy warfare methods in the region to realize their interests vis a vis each other? What is the role of external powers like the United States or Russia in proxy warfare? How does the competition between Iran and Saudi Arabia impact Pakistan?

Applications: The study concludes that the outcome of the predicament in the Middle East has produced policy challenges for Pakistan vis-à- vis its relations with Saudi Arabia and Iran. The growing threats of sectarianism, violent extremism, domestic Polarization, and danger to the economic development of Pakistan make it an important player in this competition.

Novelty: The traditional Conflict between Saudi and Iran affects the entire region of the Middle East. Sectarianism is one of the serious concerns of all Muslim countries today. It truly has both internal and external sources in other neighbouring Muslim states. Thus, this research provides an understanding to comprehend Pakistan's internal and as well as external problems.

Keyword: Pakistan, Iran, Saudi Arabia, Sectarian Proxy Warfare, Regional Influence.

\section{INTRODUCTION}

The Middle East is characterized by a situation of chaos, volatility, and a battleground of power and influence. One of the chief causes of this current scenario is the competition between Saudi Arabia and Iran. This is rooted in multiple factors, competing legitimacies, geostrategic interests, and the religious cum sectarian differences are some of them. Both are highly involved in direct and indirect proxy warfare in Syria, Yemen, Iraq, Lebanon, and Bahrain. Pakistan has a compatibility of security and economic interests with both Iran and Saudi Arabia. Pakistan aspires to deepen its ties with both these countries and wants to remain neutral in the strategic competition between Saudi and Iran, but still, its stance is prone to several vulnerabilities for which Pakistan has to respond effectively to domestic and regional developments. Options for Pakistan are very minimal as it cannot side with anyone party in the Saudi-Iran competition. This paper aims at exploring how Iran and Saudi Arabia, with, the support of allies using sectarian proxy warfare to counter each other's regional influence in the region. Does it examine the implications of this proxy war on Pakistan? The paper looks at all the available options Pakistan has in the emerging strategic situation of the Middle East. The study further considers Pakistan needs a more proactive and balanced policy in dealing with both the States in the recent regional developments. This work also recommends that Pakistan can try to help resolve some Iranian and Saudi differences. It should take rigorous measures to ensure its territory is protected from Iranian and Saudi proxies and ideological propaganda. It needs to resort to a more proactive approach vis a vis the two rivals. Pakistan should also have a sincere dialogue with Iran and Saudi Arabia over the issue of extremism and sectarianism to make them realize the enormous cost it has paid due to these proxies on its land.

Neither Iran nor Saudi Arabia can defeat each other due to their similar political and economic difficulties. Yet, the diplomatic, economic, and military leverages are large enough to perpetuate this rivalry to the end, thereby_ruining all the possibilities of a stable region (Sleiman-Haidar \& McGinn, 2018). Both Iran and Saudi Arabia are highly involved in direct and indirect proxy warfare in Syria, Yemen, Iraq, Lebanon, and Bahrain. Fueled by both Sectarianism and Power politics collectively, the Saudi-Iranian rivalry has created a defining and dangerous element of regional politics culminating in a new cold war.

The roots of this persistent conflict lie in three significant events; the 1979 Islamic Revolution in Iran, the US-Iraq war (2003), and the Arab Spring._The 1979 Islamic Revolution led by Ayatollah Khomeini initiated the wave by adding the sectarian layer to Iran's ambitions for geopolitical influence. For him, Islam was political and incited many Iraqis' Shia 
community to rise against the Sunni Baathist Saddam's Regime. His aggressive foreign policy massively threatened the Saudi Monarchy and Saudi's regional influence at the same time. The scenario depicting Saudi as status quo and Iran as revolutionary has resulted in a zero-sum security dilemma in which each of the two countries is taking actions that are meant to increase one's security while creating insecurity for the other (Sleiman-Haidar \& McGinn, 2018). Moreover, a protracted power tussle between Saudi Arabia and Iran to balance out the influence of their respective ideologies makes them involve in proxies' wars in the region. They both keep on intervening in politics and internal affairs of the neighbouring countries to avoid any chance of building each other's influence in the region. The Arab Spring opened up a new avenue for Iran to expand its influence. There started a tug of war between the two governments. On the one hand, Iran makes every effort to manipulate the already volatile situation to threaten a pro-Saudi regime in any regional country. On the other hand, Saudi never leaves any case where the Iranian friendly government finds it difficult to stay intact by further creating horrible miseries pushing it to the ultimate end (Sleiman-Haidar \& McGinn, 2018).

Pakistan has a compatibility of security and economic interests with both of the two regimes. The socio-religious linkages that it shares with the two are viewed as a product of an assortment of factors such as commonality of civilization, culture, and religion with shared interests and joint aspirations thus, tensions between the two blocs also impact Pakistan. It aspires to deepen its ties with both these countries and wants to remain neutral in the strategic competition between Iran and Saudi, but still, its stance is prone to several vulnerabilities for which Pakistan has to respond effectively to domestic and regional products. Pakistan needs a more proactive and balanced policy in dealing with both the States in the recent regional developments (Yusuf, 2017).

\section{Problem Statement}

The Saudi-Iranian strategic competition results from opposing political, ideological, religious, and sectarian aspirations that have exacerbated the regional security situation. In the pursuit of their narrative of political Islam, both countries try to reshape the regional order that would eventually help to promote their interests. Both are actively involved in political movements and funding proxies in the conflicts in their neighbouring states just to negate each other's influence. Whereas Saudi Arabia's interests lie more in maintaining the status quo, preventing the rise of all the anti-Saudi elements, Iranians, on the other hand, are engaged in tilting the status quo and spreading their type of revolution. Pakistan shares deep socio-religious linkages with both Iran and Saudi Arabia and aspires to deepens its, cordial ties with both countries and at the same time wants to remain neutral in their strategic struggle. Yet its stance is prone to several vulnerabilities for which Pakistan has to respond effectively. Pakistan faces a host of implications and adverse impacts in the wake of this rivalry. Many of the current internal security issues are directly connected to these externally sponsored factors. They pose a threat to national security and socio-economic development and allow anti-state nationalist elements to exploit the vulnerabilities. Options for Pakistan are very minimal as it cannot side with anyone party in the Saudi-Iran rivalry. Pakistan needs to ensure its territory is well protected from both Iranian and Saudi proxies and their political and ideological motives.

The primary purpose of the study is to understand how Saudi Arabia and Iran with, the support of their allies using sectarian proxy warfare to counter each other's regional influence. This work also analyzes the implications of this proxy war on Pakistan's internal and external issues.

Hypothesis: The Saudi-Iran's sectarian proxy warfare in the Middle East is a means to counter each other's regional influence that has adverse implications for the internal security of Pakistan.

\section{Research Questions}

Primary Question: How are Iran and Saudi Arabia, supporting their allies using, sectarian proxy warfare to counter each other's regional influence, and what are the implications of this proxy war on Pakistan?

\section{Secondary Questions}

- To what extent the Iran-Saudi Rivalry a result of sectarian aspirations?

- How Iran and Saudi Arabia used proxy warfare as a means for the realization of their interests in the region?

- What is the role of external powers like the US or Russia in proxy warfare?

- How does the rivalry between Iran and Saudi Arabia impact Pakistan?

\section{Significance of Research}

The traditional conflict between Saudi and Iran affects the entire region of the Middle East. Sectarianism is one of the serious concerns of all Muslim countries today. It truly has both internal and external sources in other neighbouring Muslim states. Thus, this research brings the understanding to comprehends Pakistan's problems generated due to IranSaudi proxies on its land. Pakistani Muslims have been facing this problem for many decades still the intensity of it is more manifested when it has assumed the external characteristic, especially the fallout of Middle Eastern conflicts. The Soviet intervention in Afghanistan in 1979 cleared the path for Saudi Arabia to exert its influence in this region that further intensified with the Iranian Revolution in 1979 that allowed Iran to extend its Islamic ideas in the Muslim world. 
Since then, Pakistan has been witnessed the menace of terrorism, sectarianism, and massacre in the name of religion. This study is critical in this scenario, for it will gives policymakers with a framework to ensure internal security and territorial integrity in the wake of such trends. Moreover, the research would be fruitful as it provides future peaceful political options for Pakistan.

\section{LITERATURE REVIEW}

The Literature reviewed on this particular topic can be easily subdivided into three groups. The first set describes to those sources that relate the competition between Iran and Saudi Arabia with the sectarian motives rather than the geopolitical power politics. The second set of sources put more focus on the power politics and geopolitical interests of the two regional players than on their Sectarian and ideological connections. The third set mostly talked about this competition in contact with regional dynamics and instability.

According to Alex Vatanka, the religious tensions and, the Sunni-Shiite divide between KSA and Iran have their origin in the US-led invasion of Iraq of 2003 and, more importantly, Arab Spring uprisings of 2011. Both the events have led to a devastating condition. The Iraq war empowered the Shiites in the government, while the Arab Spring uprisings led Iran to maximize its influence on the neighbouring Gulf states.

Sleiman-Haidar and McGinn (2018) argued in their study about the essence of Saudi-Iranian rivalry. He focused on their competing legitimacies. Both are determined to shape the regional order according to their aspirations and interests. Despite this fact, neither of the two rivals can marginalize or defeat one another in a complete sense. However, they have enough capability to perpetuate their confrontation through all means, be they diplomatic, economic, or military.

In another work, done by Max Fischer, it is observed that the competition between Iran and Saudi Arabia is a struggle for dominance. This struggle has led Iran and Saudi Arabia to use proxies which have triggered the region's immediate problems. Religious extremism, dictatorship, and militia violence are a few of them. So, instability, civil war, and fragmented societies are very much possible and anticipated in the region's politics (Fisher, 2016).

Beauchamp (2015) noticed that Saudi Arabia and Iran are responsible for exacerbating the mess and crisis that is going on in many Middle Eastern countries such as Lebanon, Bahrain, Iraq, and Syria. Moreover, the chief cause of the conflicts relates to the proxies employed by these two countries in their neighbuors. Iran and Saudi Arabia not only support opposing political parties in other niegbbouring Muslim states but also engaged in a confrontation with one another's proxies. Grumet (2015) also confirmed this proxy conflict and indirect warfare between Iran and Saudi Arabia in different countries of the Middle East. The whole region is polarized on a politico-religious basis into two regional armed camps. Sectarianism has been promulgated to exploit weaker states. From Iraq to Lebanon, many of the states are experiencing the proxy effects of these two traditional rivals on their lands. A New Middle East Cold war is emerging in the near scenario. Ankit Panda has approved in his work that religion and politics have played a more prominent role in the polarization that is occurring, but it has negative ramifications for the entire region as well as the whole world (Panda, 2019).

The U.S is determined to isolate Iran politically and financially to weaken its economy (Jones, 2019). The, US presence in the Gulf War has minimized the chances of building a bridge between Saudi Arabia and Iran. Sectarianism is the most significant tools that each side employs to increase one's influential sphere. The region remained divided into the two largest religious sects of Islam, Shia, and Sunni, due to their differential approaches (Rizwan et al., 2014).

Farhat Konein and Muhammad Shafiq, in their paper, argued that the messy relationship between Iran and Saudi Arabia could have huge impacts on Pakistan, which were mostly of negative nature. Pakistan, due to several social, religious, and cultural connections with the two states hopes for a shared future (Shujahi \& Shafiq, 2018). Muzaffar et al. observed that Iran enjoys a historical relationship with Pakistan as its closest neighbour, while Saudi is an important strategic partner of Pakistan. Pakistan, despite its balancing approach, finds it challenging to maintain a healthy equilibrium in the relationship towards both countries. The reason is the zero-sum security dilemma between these two enemies who perceive one's friend as the enemy of the other (Muzaffar et al., 2017). In connection with Pak-Iran relations, few scholars have even noticed that the regional dynamics, geopolitics, and external powers intervention have structured Pakistan-Iran relationship since Pakistan's birth. Both had always kept different interests, alliances, and ideologies which have affected any chance of their working relationship (Barzegar \& Divsallar, 2017).

Zulqarnain Sewag pointed out that Iran and Saudi Arabian rivalry is the root cause of many of the internal security issues of Pakistan. Sectarianism, unrest, chaos, illiteracy, and immense poverty are the daily problems that have deteriorated peace in Pakistan (Khan, 2016).

Pakistan should follow a proactive approach towards both of these rivals (Shafi, 2017). Multiple problems have emerged for the policymakers in Pakistan related to the Middle Eastern fiasco. Sectarianism, Polarization, and economic challenges lead the manner. Pakistan has to steer its domestic and International Policy direction in a workable, pragmatic, and effective way (Mumtaz, 2015).

After reading the available literature on the Saudi-Iran rival relationship, it is found that though there is abundant literature available generally on the proxy confrontations of Iran and Saudi Arabia, yet there is the shortage of literature 
on the Saudi pursuit of its proxies. How it manages to act upon its indirect strategies to be the leader of the region. Most of the literature available deals with Iranian motives, its connection with the external powers, its ulterior motives in making the non-state actors allies.

Moreover, existing literature has shown that there is a need to research on the impacts of Iran-Saudi rivalry on Pakistan. This present research will try to fulfill this gap by analyzing the negative fallouts of Middle Eastern Conflicts on Pakistan's Security and will recommend some solutions as well.

\section{RESEARCH METHODOLOGY}

This qualitative research is based on descriptive typology. It aims to assess and understand the use of sectarian proxy warfare by Saudi and Iran to nullify each other's strategic influences. Data has been collected from secondary sources such as books, researches of renowned Journals, web resources, policy evaluations, newspapers, and official reports. Data has been analyzed through the document analysis method.

\section{Theoretical Framework}

The dynamics of zero-sum competition between Iran and Saudi Arabia and its implications for the wider region can be best explored with the help of the Regional Security Complex theory. This theory was propounded by Barry Buzan and Ole Weaver, it best explains the post-cold war regional dynamics of the Middle East. It focuses on the regional security threats faced by most of the rival neighbouring States causing implacable security dilemmas by utilizing their maximum resources. Within a specific region, these states form a security complex that has interlinked and interdependent security concerns. Considering the case of the Middle East and growing aspirations of regional influences of Iran and Saudi Arabia in the region and their proxy involvement has minimized the possibilities of cooperation and increased enmities. Owing to ethnic, cultural, religious, sectarian, and political diversities, the chances of cooperation are difficult to achieve. Middle Eastern Security complex is three-dimensional. At the domestic level, Sectarian civil wars in Iraq, Syria, Yemen, and the economic disparities, ethnic issues, socio-developmental problems, and governance issues are the major hurdle to bring peace. At the regional level, the Iranian nuclear program and the rise of the Islamic State (IS), are obstructing the peace process in the Middle East. At the International level, Pakistan, Afghanistan, and the Central Asian states have been witnessing the worse impacts of Saudi-Iranian confrontation, thus widening the circle of the Security Complex and creating jolts in these countries' socio-economic and political structures (Nazir. 2019)

\section{ANALYSIS AND RESEARCH FINDINGS}

\section{Saudi-Iran Rivalry: Historical Overview}

Iran and Saudi Arabia's relationship had its origin in the early $20^{\text {th }}$ century when the relations between these two states were highly turbulent yet sociable. Several issues became the cause of ups and downs in the diplomatic ties between them (Weddington, 2017). Both states became an essential part of the US's twin pillar diplomacy in the Middle East. From the 1950s to the 1980s, Iran and Saudi were the frontline states in the US war against communism. In return, they were the huge beneficiaries of the West in terms of military, economic, and diplomatic support (Cerioli, 2018). The Iranian Revolution of 1979, however, became the breaking point that not only deteriorated the Saudi-Iran relations but it also redefined Iran's role as an anti-western and anti-imperialist nation. (Weddington, 2017). Iran desired to spread its revolutionary ideology to all parts of the region as well. However, it found it very difficult to enflame non-Shi'ites to rebel against their governments. Many Shiites did not accept and ascribe to the Khomeini's ideals and politics. They even not considered him as their spiritual leader (Weddington, 2017).

The Saudis, in the first place, tried to have shown enough flexibility to adjust to the new transitional phase of revolutionary Iran. They maintained a healthy relationship. But with the Haj incident of 1987 that killed 400 Iranian pilgrims, Saudis departed. Iran was undermining Saudi's legitimacy and validity which paved the way for Saudis to side with Iraq with full cooperation and support in Iran-Iraq War. The Gulf Cooperation Council (GCC) was established to marshal other Gulf States to help Iraq in its war struggle. Saudi Arabia preferred to assist Iraq even though victory for both Iran and Iraq would be equally unacceptable, as both could have probable dangerous aspirations and intensions towards the larger Gulf region. Thus, Iran and Iraq collectively emerged as non-victorious at the end (Shujahi \& Shafiq, 2018).

After Khomeini's death, his pragmatic successors sought a reengagement with Saudi Arabia. A rapprochement was in sight when Iran's foreign policymakers stopped advocating the dissemination of their ideology further. The focus was solely on the rebuilding of economic ties. It became more inclined in its foreign policy to inclusion into the world at large. Nevertheless, things did not go as this turn. With the reigning in of Ahmadinejad, Saudi Iran relations turned sour once again and this time fall to a minimum decline. Further discouraging were the external events like US intervention in Iraq in 2003, the fall of Iraq, and the Arab spring, which played a decisive role in the expiration of their affiliation (Muzaffar et al., 2017). These events led to the opening of new battlegrounds and the formulation of indirect proxies.

When it comes to the perspectives, Saudi and Iran contradict each other. Saudi Arabia not only considers itself as a supreme spiritual leader of the Muslim Ummah but also a wealthy, oil-rich country of the region. An active, stable, and 
prosperous Saudi monarchy would view Iran's ideology as sectarian, militaristic, and imperialist as against their satisfaction with the prevailing regional order and status quo (Shujahi \& Shafiq, 2018).

Similarly, the Iranian narrative revolves around on the emphasis of their historical, and regional ascendancy in the region. Power politics is also a prime consideration in its foreign policy crafting, just like any other state. The only variance is that of its anti-western ideology and views. While rejecting to align with the larger international community politically, Khomeini's Iran desires economic integration into global trade flows simultaneously. The political ideology of the ruling regime of Iran differentiates between the economy and politics. The government never wants to be open in national and internal security matters (Sleiman-Haidar \& McGinn, 2018). Iran, confirming its pan-Islamic ideals, rejects the prevailing order as unacceptable for Muslim Societies (Shujahi \& Shafiq, 2018).

\section{Iran-KSA Proxy Confrontation in Yemen and Syria.}

The ongoing strategic competition between Iran-Saudi Arabia has resulted in two major proxy wars in the Middle East, namely Syria and Yemen however both have been extensively engaged in other parts of the region, especially Iraq, Bahrain, and Lebanon, for gaining political influence power projection (Shujahi \& Shafiq, 2018). Both perceive that influencing neighbours' policies and regional affairs is essential to generate alliances and credibility (Cerioli, 2018). Proxy warfare is defined as a situation whereby the third parties in a conflict scenario try to involve and intervene by covert means for gaining a strategic influence in the conflict outcome (Karakir, 2018). This type of conflict requires the external actors such as states or non-states to influence the internal behaviour of internal actors by providing them with material support (Ahmed \& Akbarzadeh, 2018).

\section{Case of Yemen}

The country is impoverished in terms of resources that have contributed towards the rise of ethnic rifts and tensions during the President Saleh era. Apart from these socio-economic grievances, political problems and corruption by the ruling regime played also a pertinent deformation role in the structuring of the state. Such a scenario made all the people anti-regime and revolutionary in 2011(Sharp \& Brudnick, 2015). However, it took four to five years for these disagreements and grievances to become violent and chaotic. By 2018, Yemen experienced the most protracted and violent conflict in the Middle East. This violence has created a huge humanitarian crisis. In Yemen's crises, internal and external forces have also played their role in the aggravation of the already tense and violent situation. Among the top opposing forces, Houthis emerged as the most frustrated and most violent group (Sharp \& Brudnick, 2015).

Many scholars such as Karakir (2018) have put this Yemen conflict in the category of Proxy sectarian warfare, which has roots in the strategic and sectarian traditional antagonism between Saudi Arabia and Iran. For Saudi, intervention in Yemen is justified, because Iran has provided tremendous indirect support to the Houthi rebellious movement. Iran, despite its stressed economy, is trying to dislocate the regional countries be it Lebanon or Yemen. In doing so, it has proven proficient at manipulating fault lines among the neighbouring regional countries (Sleiman-Haidar \& McGinn, 2018).

\section{Case of Syria}

The Syrian conflict has been characterized by overlying external interests, bloody confrontation, shifted rivalries, prolonged civil war, and massive scale human displacement in the form of refugees internal and international. Three particular layers of proxies are functional in the case of Syria. The US and Russian confrontation since the very start make up the first layer. Iran and Saudi rivalry manifested in Shia Sunni competition from the second set US-Saudi supported Sunni groups against Iran-Russian sustained Assad's regime and Shiite groups form the third layer of main proxies. The complexity of war increases with the increasing involvement of Iran and its supporters (Safak \& CELIK. 2018).

Syrian Conflict manifests a highly polarized situation. While the conflict is more of a sectarian nature yet a direct faultline is not apparent. The proxy interventions of the two countries have instead, exacerbated other immediate and threatening issues of the region, such as violence and regional extremism. While for Iran, Syria heavily counts in the rational calculation of its regional cum international ambitions and targets, at the same time, Saudi Arabia wants to revise the Sunni Shiite balance in the region by offering strong resistance to Iranian's revolutionary spread. Thus, supporting Sunni rebels is seemingly the only left-out option for Saudi in their strategic analysis (Safak \& CELIK. 2018).

Saudi-Iran competition is likely to reiterate and intensify contention in the upcoming years, which includes Iran's covert support to the proxy groups fighting in the Middle Eastern conflict. Iran is fighting against Saudi Arabia through these groups in Yemen, Syria, Bahrain, and Iraq. Although Saudi Arabia is also alleged to support the proxy groups, it is not as strong as the Iranian support (Shujahi \& Shafiq, 2018).

\section{Role of Major Powers in the Sectarian Conflicts}

\section{Role of USA}

The chief objectives of the US in the Middle East are manifold. These goals are maintaining predominance in the region 
by employing all means of national power, ensuring the smooth and accessible supply of oil for itself and its European and Asian allies and also preventing the spread of nuclear weapons in the region, and obstructing any potential power to gain influence that can jeopardize US politico-economic interests (Zulfqar, 2018). For meeting its targets, the US has entered into several defense treaties and gained access to essential bases and territorial rights. These treaties made the US one of the largest arms suppliers to the Middle East. In these arrangements, the US becomes a security guarantor for the region's security (Zulfqar, 2018).

The US has complete moral, logistic, and intelligence support for Saudi-led efforts in Yemen since Obama's administration. Present-day US strategy towards the Middle East part revolves around cuddling Saudi. Hence it is involved in almost all the crises going on in the region. Yemen and Syria are good examples. The US role in Yemen is that of highlighting the Iranian involvement and support to Houthis. In Syria, however, in the absence of any legal authorization by the United Nations Security Council (UNSC) to resort to the use of force, the role remained vocal in bringing forth the Syrian National Coalition to provide the opposition forces a legal international recognition (Zulfqar, 2018).

\section{Role of Russia}

Counteracting secessionist movements in the North Caucasus region has been one of the chief motives for Russia in the Middle East. For this, Russia keeps on accusing the Arab states particularly the Gulf countries to have sponsored extremism and rebellion. After the 9/11 attacks that, resulted in a war against terror, Russia got the opportunity, to be a western ally. Russia has played a tiny role in the Arab states' economies, especially the Gulf states, despite its economic aspirations. Russia has a balancing approach towards the region. While having effective links with Iran and attuned states, Russia has compatibility of interests with Israel as well. Hence it emerged as the second-largest arms export dealer in the Middle East.

Russia has been involved in Yemen through all means, be it diplomatic, informal, or economic. For Russia, Yemen's seaports have a strategic importance that could be used for its naval fleet. Moreover, the most important Russian involvement has been through the use of private military companies (PMCs) since 2014, whereby retired service members are recruited and sent to conflict zones as contractors, which can ensure the decisive role of Russia as a peacemaker in the country. Russia has also offered its mediatory role in the effective resolution of the Conflict (Ehteshami, 2014).

Since the Cold war, Russia's role in Syria has been that of a strategically. Russia has implemented its veto power at three crucial times to block the burden of sanctions or force against the Syrian regime. Russia is one of the chief supporters of Assad's regime. Russia has always provided good military, logistical and political assistance to the Syrian government. Additionally, Russia's naval interests regarding the strategic base at Tartus are a compelling reason for Russian's support of Assad (Zulfqar, 2018).

\section{Implications for Pakistan}

Pakistan enjoys a cordial and brotherly relationship with Saudi Arabia since its independence. This relationship had not only religious affiliation but also based on generosity that Saudi offers in the form of economic assistance to Pakistan. Both the countries have also concluded multiple defense agreements (Sewag. 2019). On the other hand, Iran is also a significant Muslim neighbouring country that shares multiple regional interests with Pakistan. For Pakistan, siding with anyone contestant in the Saudi-Iran competition creates a set of adverse implications. At the same time, choosing to remain neutral maybe a luxury desired because Pakistan for Pakistan to defend itself from Iranian or Saudi regional strategies that may adversely - even inadvertently - impact Pakistan's national interests. There are many implications of the sectarian rife between Saudi Arabia and Iran in the Middle East on Pakistan. These are as follows;

\section{Using Islam for Vested Interests}

Each section of Pakistani society has become prone to jumble Islam for its vested interests. The religion Islam is not valid in practice due to the transgressions of its followers. Which has resulted in a series of problems such as rising sectarianism, internal chaos, anarchy, pessimism, grave illiteracy, and enormous poverty. Iran and Saudi Arabia have been continuously acting as stimulating factors. The growing nexus between these countries and hardliners in Pakistan has led to a series of internal security issues and daunting challenges for the government. Likeminded groups have joined each other for common objectives (Shujahi \& Shafiq, 2018).

\section{Sectarian Tensions in Pakistan}

In the recent past, there is news regarding Saudi and UAE findings of ultra-conservative Sunni groups and madrassas operating in Balochistan, province of Pakistan. Some of these funding channels are allegedly linked to banned groups like Lashkar-e-Jhangvi, Ahle-Sunnat-Wal-Jamaat (Shujhai. 2019). Despite dismantling all these threats by Pakistan, Iran Pak ties have experienced a downward flow due to the killing of Iranian border guards and other anti-Iran activities of these banned groups. Iran, on the other hand, is also alleged to be backing and supporting some of the sectarian groups in Pakistan as the 'Zainebiyoun' Brigade supported by Iran has been reported to be recruiting Pakistan Shia fighters to fight in the Middle East (Shujahi \& Shafiq, 2018). 


\section{Polarization in Pakistan}

The ups and downs in middle eastern politics and the resulting security challenges have increased the chances of unanticipated polarization in Pakistani public opinion. Both Saudi Arabia and Iran have sympathizers in Pakistan mainly because of their affiliations with respective sectarian affinities, Sunnis are pro-Saudi, whereas Shias are pro-Iranian. The Liberal-conservative polarization is increasingly visible, with the former taking a clear pro-neutrality work and the latter leaning towards the Saudi position.

\section{Impact on Pakistan Economy}

Pakistan's economy can have severe ramifications by the Middle Eastern situation. The chaos in the region may obstruct the drift of huge remittances sent by the Pakistani employees working in the Gulf States and empower the economy. If this situation continues, the remittances will decrease which could lead to catastrophic consequences for Pakistan's economy. That may also create unemployment for Pakistani workers working overseas (Panda, 2019).

\section{CONCLUSION}

This paper argued that the Saudi-Iran's sectarian proxy warfare in the Middle East is a means to counter each other's regional influence that has adverse implications for the internal security of Pakistan. The Iran-Saudi relationship is a story of competition and antagonism based on religious and ideological aspirations. Both the countries have increasingly sabotaged the peace and stability of the region by following their versions of political Islam. It is acknowledged that the patronage provided by the two Islamic Sects-Shia and Sunni is one of the root causes of their competition (Afzal, 2019). This confrontation has led to the unbalancing of power and resources in the Middle East and igniting the sectarian fire between Shias and Sunnis. Iran and Saudi Arabia's contradictory relationship is poised on maintaining a regional balance of power in political cum religious spheres. The struggle is indirect, which involves proxies and ideological propagation. However, in the guise of sectarianism, they are seeking regional partners and durable alliances. The Middle Eastern situation demonstrated the gruesome reality of what happens when state rivalries, separatist movements, and terror groups all come to play together. The upshot of the Middle eastern imbroglio has challenged the Pakistani policymakers from multiple dimensions vis-à- vis its relations with the Middle East. Sectarianism, Extremism, and Polarization are the topmost among these evils (Aftandilian, 2018).

\section{RECOMMENDATIONS}

Pakistan in such a scenario is left with minimum options that revolve around few recommendations. Pakistan can try to help resolve some Iranian and Saudi differences. It should take rigorous measures to ensure its territory is protected from Iranian and Saudi proxies and ideological propaganda. It must take a proactive approach vis a vis the two rivals. Pakistan should also have a sincere dialogue with Iran and Saudi Arabia over extremism and sectarianism in Pakistan. It is paying a massive cost due to these problems that must be realized and recognized by the two. Pakistan may also enhance its internal security mechanism to enable it to deal with matters of immense importance for its security (Mumtaz, 2015).

\section{ACKNOWLEDGEMENT}

The present study owes a debt of gratitude to all the contributors of this studies, who themselves bear all the intellectual and financial pains to finish this.

\section{AUTHORS' CONTRIBUTION}

Author 1: Float the main idea and works on theory and data.

Author 2: Devised the methodology and go through the literature review to provide a solid foundation of this study.

Author 3: Over all supervise this work and corresponds with the journal.

\section{REFERENCES}

1. Aftandilian, G. (2018). Maneuvering the Saudi-Iranian Rivalry in the Middle East: How the United States Can Preserve and Protect Its Long-Term Interests in the Region. Independently published December 7, 2018.

2. Afzal, M. (2019). Saudi Arabia's hold on Pakistan https://www.brookings.edu/wpcontent/uploads/2019/05/FP_20190510_saudi_pakistan_afzal.pdf

3. Ahmed, Z. S., \& Akbarzadeh, S. (2018). Understanding Pakistan's Relationship with Iran. Middle East Policy, 25(4), 86-100. https://doi.org/10.1111/mepo.12380

4. Barzegar, K., \& Divsallar, A. (2017). Political rationality in Iranian foreign policy. The Washington Quarterly, 40(1), 39-53. https://doi.org/10.1080/0163660X.2017.1302738

5. Beauchamp, Z. (2015). Iran and Saudi Arabia's cold war is making the Middle East even more dangerous. Vox,(March 30, 2015), retrieved from https://www.vox.com/2015/3/30/8314513/saudi-arabia-iran

6. Cerioli, L. G. (2018). Roles and International Behaviour: Saudi-Iranian Rivalry in Bahrain's and Yemen's Arab Spring. Contexto Internacional, 40(2), 295-316. https://doi.org/10.1590/s0102-8529.2018400200010

7. Ehteshami, A. (2014). Middle East Middle powers: Regional role, international impact. Uluslararası İlişkiler Dergisi, 11(42), 29-49. https://doi.org/10.33458/uidergisi.553296 
8. Fisher, M. (2016). How the Iranian-Saudi proxy struggle tore apart the Middle East. The New York Times, 19.

9. Grumet, T. R. (2015). New Middle East Cold War: Saudi Arabia and Iran's Rivalry.

10. Jones, S. G. (2019). War by Proxy: Iran's Growing Footprint in the Middle East. Center for Strategic \& International Studies.

11. Karakir, İ. A. (2018). Ongoing conflict in Yemen: A proxy war? TESAM Akademi, 5(2), 121-149. https://doi.org/10.30626/tesamakademi.456008

12. Khan, Z. (2016). Sectarian Rise in Pakistan: Role of Saudi Arabia and Iran. Researcher in Government and Public Policy, National Defence University, Islamabad, Pakistan.

13. Mumtaz, K. (2015). The Middle East in Flux. Strategic Studies, 35(2), 136-156.

14. Muzaffar, M., Khan, R., \& Yaseen, Z. (2017). Saudi-Iran Strife: Complexities for Pakistan. Global Regional Review, 2(1), 119-134. https://doi.org/10.31703/grr.2017(II-I).09

15. Panda, A. (2019). Pakistan's Approach to Navigating the Saudi-Iranian Split. JSTOR.

16. Rizwan, M., Arshid, M., Waqar, M., \& Iram, S. (2014). From rivalry to nowhere: A story of Iran-Saudi ties. Journal of Humanities and Social Science, 19(9). https://doi.org/10.9790/0837-199491101

17. Şafak, O., \& ÇELİK, K. E. (2018). Conflict in Syria: Is It a Proxy Warfare? Uluslararası Kriz ve Siyaset Araştırmaları Dergisi, 2(2), 44-69.

18. Shafi, H. A. (2017). Iran-Saudi rivalry: Options for Pakistan. Spearhead.

19. Sharp, J. M., \& Brudnick, I. A. (2015). Yemen: civil war and regional intervention. In: Congressional Research Service Washington DC.

20. Shujahi, F. K., \& Shafiq, M. (2018). Evaluating iran-saudi strategic competition in middle east: implications for regional security. NDU Journal, 13(3). https://ndu.edu.pk/issra/issra_pub/articles/ndu-journal/NDU-Journal2018/13-Eval-Iran-Saudi-Strat.pdf

21. Sleiman-Haidar, R., \& McGinn, J. (2018). Saudi Arabia and Iran: beyond conflict and coexistence?

22. Weddington, D. (2017). Rivalry in the Middle East: The History of Saudi-Iranian Relations and its Implications on American Foreign Policy.

23. Yusuf, H. (2017). Pakistan in the Middle East: A Cautious Balance. The Diplomat.

24. Zulfqar, S. (2018). Competing interests of major powers in the Middle East: The case study of Syria and its implications for regional stability. PERCEPTIONS: Journal of International Affairs, 23(1), 121-147. 